\title{
Efficiency Analysis of Russian Rail Freight Transportation Companies with Super Slack- Based Measurement Data Envelopment Analysis
}

Author(s): Valeria Maltseva, Joonho Na, Gyuseung Kim, Hun-Koo Ha

Source: Journal of International Logistics and Trade 2020; 18(2):77-89

Published by: Jungseok Research Institute of International Logistics and Trade, Inha University

DOI: https://doi.org/10.24006/jilt.2020.18.2.077

The Journal of International Logistics and Trade is an official journal published by Jungseok Research Institute of International Logistics and Trade, Inha University, Korea. JILT welcomes manuscripts that advance the practice and science of logistics, trade, and other related fields.

Frequency: Quarterly (March, June, September, December)

Stable URL: https://www.ejilt.org

The Jungseok Research Institute of International Logistics and Trade is a specialized academic research institute representing Inha University and the Inha Foundation in Korea. The institute aims to become a representative institute in Northeast Asia in the research of logistics and trade.

Stable URL: https://jrieng.inha.ac.kr

(C) Copyright. Jungseok Research Institute of International Logistics and Trade.

This is an Open-Access article distributed under the terms of the Creative Commons Attribution NonCommercial License (http://creativecommons.org/licenses/by-nc/4.0/) which permits unrestricted noncommercial use, distribution, and reproduction in any medium, provided the original work is properly cited 


\title{
Efficiency Analysis of Russian Rail Freight Transportation Companies with Super Slack-Based Measurement Data Envelopment Analysis
}

\author{
Valeria Maltseva, Joonho Na, Gyuseung Kim, Hun-Koo Ha* \\ ${ }^{1}$ Graduate School of Logistics, Inha University, Incheon 22212, Korea
}

Received $\quad$ March 19, 2020
Revised $\quad$ May 20, 2020
Accepted June 06, 2020

*Corresponding author: Hun-Koo Ha
Asia Pacific School of Logistics/Graduate
School of Logistics, Inha University,
Incheon 22212, Korea
Tel: +82-32-860-8232
E-mail: hkha@inha.ac.kr

\begin{abstract}
We adopt a super slack-based measurement (SBM) data envelopment analysis (DEA) model to estimate the efficiency of five biggest freight rail operators in Russia, which are included in the top 30 freight rail operators in terms of two dimensions - financial and operational efficiency during 2013-2017. The result shows that the private companies characterized by high financial and operational efficiency, while the Rossiiskye Zheleznye Dorogi (RZD) subsidiaries characterized by sufficiently low financial and operational efficiency scores. And the result also presents that operational efficiency score of operators handling universal rolling stock is higher than financial efficiency scores. In contrast, financial efficiency scores of operators handling special rolling stock is higher than operational efficiency scores. rail freight operators in addition to a special rolling stock park should have a universal rolling stock park for higher profitability. State-owned companies and its subsidiary operate inefficiently in the midst of a market economy in Russia. Rail freight operators for a higher level of financial efficiency should be transferred to the private sector.
\end{abstract}

Keywords Russian freight rail operators, Financial efficiency, Operational efficiency, Super slack-based measurement (SBM), Data envelopment analysis (DEA)

\section{Introduction}

The transport complex plays an important role in the Russian economy. The share of freight transport in GDP is $6 \%-8 \%$, the share of fixed production assets attributable to the transport sector is about $28 \% .6 .3 \%$ of the total able-bodied population of Russia works in the transport field (Reutov 2017). Transport communications provide a link between all regions of the country, which is a necessary condition for its territorial integrity, the unity of its economic space. Railway plays an integral part in the movement of freight in Russia. Russia is the world's largest country with 17 million square kilometers, which is more than $10 \%$ of the Earth's landmass. Rail transportation is therefore a vital component of the Russian economy. With over 85 thousand kilometers of track spanning Russia, about $87.1 \%$ of the country's overall freight turnover in 2016, excluding pipeline traffic, travels by rail. That equates to almost 2.4 billion tons of cargo a year. The length of the Russian railway network is in third place in the world, as of the end of 2016. Nevertheless, Russia uses its railways at times more intensively than many other countries. Relative freight turnover is 25 million tons per year, which is almost 2.5 times higher than in India, the United States and Brazil, and 7.5 times higher than in Germany, but somewhat less than in China. The share of railway transport in all types of freight turnover transport in Russia exceeds $46 \%$, and excluding the pipeline amounts $87 \%$ (Federal State Statistics Services 2017). Russian Railways generates about $1.6 \%$ of Russia's GDP, gives $1.3 \%$ of all tax revenues to the budget and $3.4 \%$ of investments in fixed assets (Lapidus 2014).

The railway industry is tightly regulated by the Government of Russia. The legal aspect and aspect of direct government control are key to the Russian rail freight market. Presently, the Russian rail freight market is only at the stage of its formation. Until the reforms that occurred in the early 1990s that changed the Russian economy from a planned one to a market one, the railway industry functioned as a single entity - the Ministry of Railways of the Russian Federation. For a number of reasons, which should be attributed to the chronic underfinancing observed in the 1990s, it had been decided to reform the railway transport industry.

The railway transport reform is implemented on the basis of the Program of Railway Sector Structural Reform approved by Russian Federation Government Decree \#384 of 18 May 2001. The declared goals of the reform were to introduce competition 
and facilitate private investment in the industry, improve service quality, sustainability and safety, and reduce the economic costs of transportation. The program envisaged three phases. The first phase (2001-2003) was aimed to separate the policymaking and regulatory functions from business management and operations. To achieve this, a 100\% state-owned joint-stock company "Russian Railways" Rossiiskye Zheleznye Dorogi (RZD) was established. The "policy-making" segment of Ministerstvo Putei Soobschenija (MPS) was integrated into the Ministry of Transport. RZD inherited all the basic assets of MPS, while numerous non-core structures such as hospitals, schools, etc. were divested. At the same time, a considerable number of new legal acts were adopted in order to prepare the transition from state-owned railway monopoly to the competitive railway industry. The second phase of the reform (2003-2005) was aimed at RZD corporate restructuring and further marketoriented legal base improvement. During this period certain business lines and activities within the company were institutionally and legally separated. In the legal sphere the principle of non-discriminatory access to railway infrastructure was declared, although RZD was still the only railway carrier. During this period the segment of so called "wagon operators" was rapidly growing up to eventually become one of the principal components of the Russian railway market model. The third phase of the reform (2006-2010) was planned to be a period of intensive attraction of private capital to the industry. Some of the RZD subsidiaries were to be privatized. It was planned to create a competitive market for freight transport services and, probably, long haul passenger transportation.

After the reform of rail transport in Russia, the operator activity was almost completely removed from the sphere of activity of Joint Stock Company (JSC) Russian Railways - the state own company. At present, the bulk of freight traffic is carried out in private wagons, the rent for which is set by the owners of the rolling stock in a free mode, and carriers pay Russian Railways for the using of infrastructure and the provision of locomotive traction at tariffs set by the Federal Customs Service of Russia. Regulation of competition and innovations in the railway sector in Russia takes place mainly on the governmental level, and the document created in 2001 and amended in 2009 "On Structural Reform Program for Railway Transport". One of this Program goals was the development of a competitive sector in the field of rail transport, including the creation of commercial companies. Russian rail freight market has changed fundamentally after reforms during last 20 years. Nowadays in Russia, there are about 2.5 thousand owners of rolling stock, which have from one to several thousand cars and around 700 rail freight operating companies. Two-thirds of the park are managed by 25 large companies. One of the difficulties is the fact that currently, there are no criteria in the regulatory framework in Russia that would separate the owner of rolling stock from the operator, as well as to divide operators into groups (Analytical Center under the Government of the Russian Federation 2015).

The structure of the railway industry in Russia today is the infrastructure of public railway transport (road, track facilities, railway stations, etc.) is almost entirely owned by Joint-Stock Company (JSC) Russian Railways, which is providing infrastructure services as "natural monopoly". The majority of the country's rail infrastructure network and the locomotive fleets are owned by JSC Russian Railways (RZD), a state-owned-enterprise, operating freight and passenger railway services (JSC RZD 2014). Regulation of competition and innovations it the railway sector in Russia takes place mainly on the governmental level. Figure 1 shows the structure of Russian railway freight market nowadays. The Federal Law on Railway Transport in Russian Federation of 19 May 2003 provides a legal basis for the organization of the sector and the legal relationships between the owners of railway assets, shippers and State authorities. Conceptually it divides rail transport between

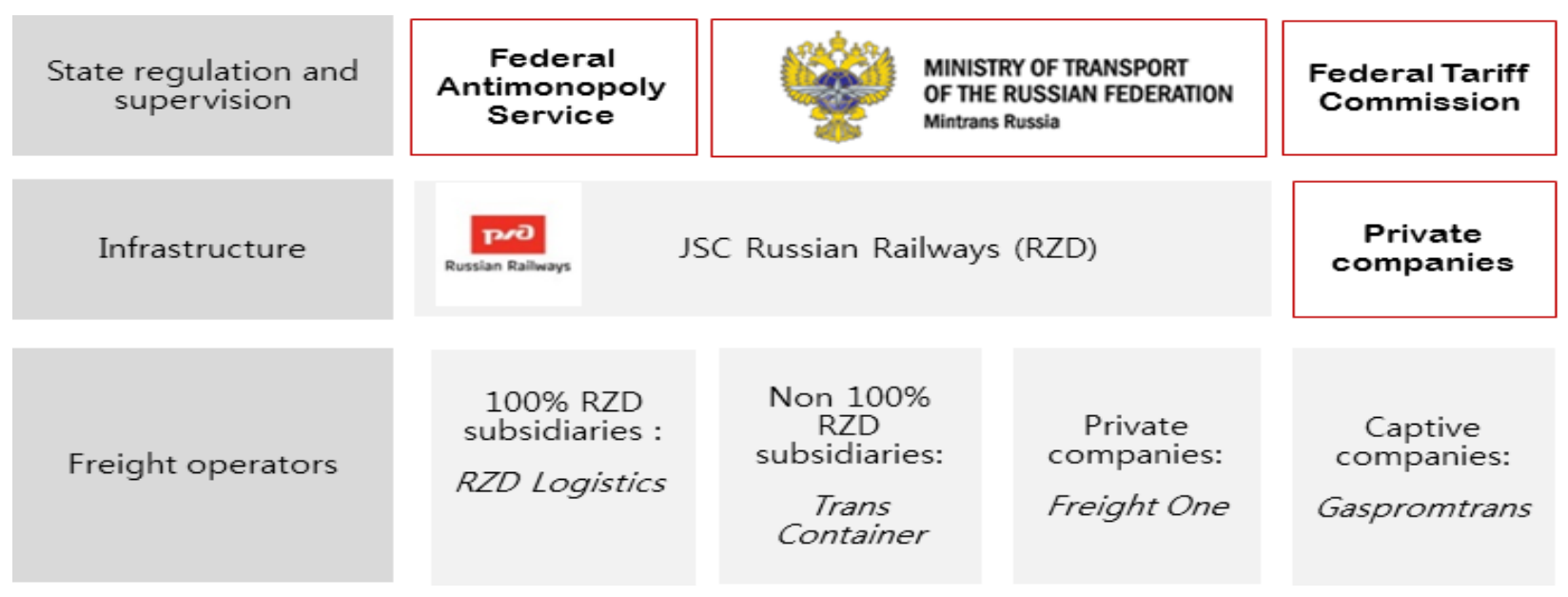

Figure 1. Structure of Russian Railway freight market. 
infrastructure services and train operations and provides the framework for legal relationships between the two. The relationship diagram of the state and the railway is quite clear: the state is in a leading position, JSC RZD is guided. Besides JSC RZD, the Russian railway complex also comprises operations of private rail companies and industrial enterprises that have their own fleets of locomotives and railcars, and their own networks of rail tracks. Compared to RZD, their share of locomotives is rather insignificant (1,163 versus 20,300), while the share of freight railcars is much greater (1,123,012 versus 95,157). The freight operators by ownership can be divided into 4 groups: 100\% JSC RZD subsidiaries, none $100 \%$ JSC RZD subsidiaries, private companies and captive companies (JSC RZD 2016).

The basis for the analysis was the actual change in the competitive environment in commodity markets. Considering an increasing number of freight rail operating companies, study will answer the question: how effective these companies are? and try to find the reasons. Yu et al. (2014) points out that the efficiency assessment of business firms is an important issue, which encompasses all business players, including managers, shareholders, and investors. Efficiency assessment demonstrates how shareholders and investors interests are affected, it informs on whether existing company resources are used effectively and efficiently and motivate firms to implement strategies for further improvements. Sufian (2007) considers that improving operational efficiency has a direct impact on the organizations profit margins and efficient firms are more cost-effective. The operational efficiency aspect for any type of business is vital and must be considered by management in order to earn healthy and sustainable financial performances.

To the best of our knowledge, this study contributes to literature in the following aspects. First, we examine the special characteristics of the Russian rail freight market and provide further information for academia as well as the international railway freight market. Second, several surveys of analysis of rail transport operating performance have been conducted using non-parametric data envelopment analysis (DEA) models. The analysis of rail freight system operations using various DEA models in conjunction with other methods has been addressed by several papers involving cargo and passenger railway worldwide. Although DEA has been applied to the railways in previous studies, however, operation and financial performance have never been explicitly incorporated into frameworks of performance measurement. Such studies of efficiency measuring in railway industry in Russia are sparse, perhaps justified by the smaller relative share held by the rail mode in the transport matrices of the country. The research on the performance evaluating of the rail freight operators in Russia with using super slack-based measurement (SBM) data envelopment analysis (DEA) constitutes a methodological structure never before used to assess the efficiency of Russian rail freight companies.

The remainder of the paper is organized as follows. Section 2 contains the literature review. Section 3 describes the proposed super SBM DEA model for measuring the efficiency of rail freight operating companies in Russia. Section 4 presents the analysis of the financial and operating efficiency of rail freight operating companies in Russia. Section 5 elaborates the conclusions of the study and provides policy implications.

\section{Literature review}

The theoretical foundations of performance evaluation are found in the literature of performance management, which includes and also precedes performance measurement. Founder of the principles of management, Drucker (1954) considers that few things are important to a firm's performance as performance measurement. Kouachi and Talal (1998) has recognized that traditional measurement has based on the financial indicators focused on the profit earned from the activity. Even though this measure is an essential and vital element in the performance evaluation process. However, because of the evolution of life aspects in the great development of various technology and information which is, make it possible to have mas production operations. Financial measurement element alone becomes insufficient to give a clear view of the actual position of the organization, and it was necessary to add other indicators related to non-financial aspects of performance - operational efficiency.

According to Kalluru and Bhat (2009), operational efficiency is the proficiency of a corporation to curtail the unwelcome and maximize resource capabilities to deliver quality products and services to customers. An operational efficiency depends on factors like skillful and proficient workers, proper technological progression, proper procurement carries out, return to scale of the businesses, supply chain controlling among many others. A definition of the concept of operational freight transport efficiency is difficult to find in transportation literature. Arvidsson (2011) put together the definitions of other researchers and defined it as a set of utilization measures of time, space, vehicle, fuel and driver in the movement of goods. This study is grounded on evaluating the financial efficiency and operational efficiency of the rail operating companies in Russia with data envelopment analysis.

Since European member states have chosen such different models of rail organization within the given European Union framework, 
it is fruitful to policymakers, regulators and especially to the railway companies themselves to develop transparent comparison methods. There are several approaches to the measurement of efficiency of the railway industry. Atkinson and Cornwell (1998) conducted a panel study for 12 railway companies in the USA, covering the period of 1951-1975. Their analysis was a fixed effect econometric modeling framework. Oum et al. (1999) point out that the most widely used measure in railways is the partial productivity measure (PPM), where an output indicator of an organization is viewed in relation to a single input indicator. The second measure is the total factor productivity (TFP) index, which considers multiple inputs and outputs together. More sophisticated tools for longitudinal and cross-sectional (or national) efficiency and productivity analysis include DEA for rather small datasets and two parametric methods, corrected ordinary least squares (COLS) and last is stochastic frontier analysis (SFA), where a larger sample is available.

DEA has become the most common method applied in railway efficiency analysis in recent years. DEA model was presented by Charnes, Cooper and Rhodes in 1978 - based on Farell's (1957) former work (Charnes et al. 1978). Bookbinder and Qu (1993) adopted DEA to measure the efficiency of two Canadian and five US railways. Oum and Yu (1994) applied DEA to analyze railway efficiency in 19 OECD countries. Cowie (1999) employed DEA to compare the efficiency between private railway and public railway in companies in Europe. Cantos et al. (1999) used the non-parametric method to analyze the development of the efficiency of the railway companies in Europe from 1970 to 1995. This study has determined that many companies have experience reform process and that increase the efficiency from 1985 to 1995. Cantos and Maudos (2001)

\section{Table 1. List of literature on railway efficiency}

\begin{tabular}{|c|c|c|c|c|}
\hline Author(s) & Title & Method & Input & Output \\
\hline $\begin{array}{l}\text { Marchetti and } \\
\text { Wanke (2017) }\end{array}$ & $\begin{array}{l}\text { Brazil's rail freight transport: Efficiency analysis } \\
\text { using two-stage DEA and cluster-driven public } \\
\text { policies. }\end{array}$ & $\begin{array}{l}\text { DEA CCR / BCC } \\
\text { Bootstrap truncatedregression }\end{array}$ & $\begin{array}{l}\text { 1) No. of wagons (in } \\
\text { circulation) } \\
\text { 2) No. of employees }\end{array}$ & $\begin{array}{l}\text { 1) Ton-km } \\
\text { 2) TKU }\end{array}$ \\
\hline $\begin{array}{l}\text { Merkert et al. } \\
(2010)\end{array}$ & $\begin{array}{l}\text { Benchmarking of train operating firms }-\mathrm{a} \\
\text { transaction cost efficiency analysis. }\end{array}$ & $\begin{array}{l}1 \text { stage - Super Efficiency } 2 \\
\text { stage -Tobit Regression/ } \\
\text { Bootstrap Truncacted } \\
\text { Regression }\end{array}$ & $\begin{array}{l}\text { 1) No. of employees } \\
\text { 2) Capital }\end{array}$ & $\begin{array}{l}\text { 1) Train-km } \\
\text { 2) Ton-km } \\
\text { 3) Passenger- } \\
\text { km }\end{array}$ \\
\hline $\begin{array}{l}\text { Kabasakal et } \\
\text { al. (2015) }\end{array}$ & $\begin{array}{l}\text { Efficiency determinations of the worldwide railway } \\
\text { companies via DEA and contributions of the } \\
\text { outputs to the efficiency and TFP by panel } \\
\text { regression. }\end{array}$ & $\mathrm{CCR}, \mathrm{BCC}$ & $\begin{array}{l}\text { 1) No. of employees } \\
\text { 2) Length of main line } \\
\text { 3) No. of wagon } \\
\text { 4) No. of passenger } \\
\text { wagons } \\
\text { 5) No. freight wagons }\end{array}$ & $\begin{array}{l}\text { 1) Passenge } \\
\text { 2) Passenger- } \\
\text { km } \\
\text { 3) Ton } \\
\text { 4) Ton-km } \\
\text { 5) Revenues }\end{array}$ \\
\hline $\begin{array}{l}\text { George and } \\
\text { Rangaraj } \\
(2008)\end{array}$ & $\begin{array}{l}\text { A performance benchmarking study of Indian } \\
\text { Railway zones. }\end{array}$ & DEA RCCR & $\begin{array}{l}\text { 1) Operating expenses } \\
\text { 2) Tractive effort } \\
\text { 3) Equated track km } \\
\text { 4) No. of employees } \\
\text { 5) No. of passenger } \\
\text { carriages } \\
\text { 6) No. of wagons }\end{array}$ & $\begin{array}{l}\text { 1) Passenger- } \\
\mathrm{km} \\
\text { 2) Ton-km }\end{array}$ \\
\hline Daniel (2008) & $\begin{array}{l}\text { Productivity and efficiency in urban railways: } \\
\text { Parametricand non-parametric estimates. }\end{array}$ & DEA & $\begin{array}{l}\text { 1) No. of employees } \\
\text { 2) Fleet capacity } \\
\text { 3) Rout length }\end{array}$ & $\begin{array}{l}\text { 1) Car/km per } \\
\text { year } \\
\text { 2) Volume of } \\
\text { demand }\end{array}$ \\
\hline $\begin{array}{l}\text { Cantos and } \\
\text { Maudos } \\
(2001)\end{array}$ & $\begin{array}{l}\text { Regulation and efficiency: } \\
\text { the case of European railways. }\end{array}$ & DEA & $\begin{array}{l}\text { 1) No. of wagons } \\
\text { 2) No. of employees } \\
\text { 3) Length of network }\end{array}$ & $\begin{array}{l}\text { 1) Passenger- } \\
\mathrm{km} \\
\text { 2) Ton-km }\end{array}$ \\
\hline $\begin{array}{l}\text { Cantos et al. } \\
(1999)\end{array}$ & $\begin{array}{l}\text { Productivity, efficiency and technical change in the } \\
\text { European railways: A non-parametric approach. }\end{array}$ & MPI, TFP, DEA & $\begin{array}{l}\text { 1) No. of employees } \\
\text { 2) Consumption of } \\
\text { energy and } \\
\text { materials } \\
\text { 3) No.of passenger } \\
\text { carriage } \\
\text { 4) No.of freight cars } \\
\text { 5) No.of kilometers of } \\
\text { track }\end{array}$ & $\begin{array}{l}\text { 1) Passenger- } \\
\mathrm{km} \\
\text { 2) Ton-km }\end{array}$ \\
\hline
\end{tabular}


conduct the cost and revenue frontier function to evaluate the cost and revenue efficiency of European railways. This study showed that the long period of railway regulation in Europe was the substantial growth in levels of productivity, explained partly by the companies' improved efficiency. Most of the literature investigates technical efficiency, such as Cantos et al. (1999), Daniel (2008) compared parametric and non-parametric approach in the railway industry. Recently papers used twostage analysis. Yu (2008) evaluated the efficiency of 40 global railway companies adopted traditional DEA and network DEA methods using data for 2002. Merkert et al. (2010) used the two-stage DEA method to measure the 43 railway organizations in Sweden, Germany and the United Kingdom and then they applied Tobit regression to the productivities. They found that the transaction factors were more determinative in achieving technical efficiency than the corporate factors.

$\mathrm{Li}$ and $\mathrm{Hu}$ (2010) adopted the DEA-Tobit approach to evaluate the efficiency of the regional railway in China. They measured the railway efficiency by DEA and Malmquist productivity index (MPI) from both static and dynamic viewpoints, and then identifies the key factors affecting railway efficiency by Tobit regression. Movahedi et al. (2011) used the DEA analyzed Iran railway efficiency comparison with other countries. Kabasakal et al. (2015) evaluate the operating efficiency of worldwide thirty-one railway companies using the DEA model from 2000 to 2009. The study also conducts the Malmquist index to investigate the total factor productivity for the sample period. Marchetti and Wanke (2017) use DEA to assess the efficiency of Brazilian rail concessionaires between 2010 and 2014 with Bootstrap Truncated Regression.

Although DEA has been applied to the railways in previous studies, Table 1 reveals that operation and financial performance have never been explicitly incorporated into frameworks of performance measurement.

\section{Methodology}

DEA is a nonparametric method in operations research and economics for the estimation of production frontiers. It is used to empirically measure productive performance of decision making units (DMUs). Since the advent of DEA, which was first introduced by Charnes et al. (1978), many papers of evaluation railway efficiency have been published on its methodology and applications. There are two types of DEA models, the radial and non-radial models. The Charnes, Cooper, and Rhodes (CCR) model measures the radial efficiency of the inputs (input- oriented) or outputs (output-oriented) by gauging the ratio of the inputs to be contracted or the ratio of the outputs to be enlarged so that the evaluated DMU becomes efficient. One of the limitations of radial models is that radial efficiency does not reflect all inefficiency of a DMU. Slacks need to be considered simultaneously with radial efficiency to identify the "real" projection of a DMU. To overcome this, Charnes et al. (1984) developed additive model of DEA, which deals with input excesses and output shortfalls directly. Though the additive model can dis- criminate between efficient and inefficient DMUs, the model provides no efficiency measure so that decision maker can tell how well a DMU performs. In light of these issues, Tone (2001) proposed a non-radial model called SBM, which uses the term "slacks" to represent the input excesses and output shortfalls and deals with them directly and by maximizing theses slacks. The hallmark of SBM is that SBM provides efficiency score which is units- invariant and a monotone function of input slacks and output slacks.

To overcome the ties of efficient DMUs, Andersen and Petersen (1993) proposed a radial super-efficiency model under the condition of constant returns to scale (CRS). The super-efficiency model under the condition of variable returns to scales (VRS) may suffer from infeasibility. Chen et al. (2013) proposed a modified VRS super- efficiency model which successfully addresses the infeasibility issues. As a non-radial approach, Tone (2002), based on SBM, proposed another model to rank efficient DMUs. Tone's Super SBM requires that standard SBM is run first to classify efficient and inefficient DMUs, and next Super SBM is run only for the efficient DMUs.

Previous study on the evaluation of railway operation performance mainly adopts such basic models as CCR and Banker, Charnes, and Cooper (BCC) as DEA model and there are a large number of assumptions in the model which deviate from reality. In This study, we first introduce the original SBM model developed by Tone (2001).

\subsection{SBM-DEA model}

Assume that there are $n$ DMUs with the input and output matrices $X=\left(\chi_{i j}\right) \in R^{m \times n}$ and $Y=\left(y_{i j}\right) \in R^{s \times n}$, respectively. We assume that that the data set is positive, i.e. $X>0$ and $Y>0$.

The production possibility set $P$ is defined as

$$
p=\{(x, y) \mid x \geq X \lambda, \mathrm{y} \geq Y \lambda, \lambda \geq 0\}
$$


where $\lambda$ is a non-negative vector in $R^{\mathrm{n}}$

$$
\begin{aligned}
& x_{0}=X \lambda+s^{-}, \\
& y_{0}=Y \lambda-s^{+}
\end{aligned}
$$

with $\lambda \geq 0, s^{-} \geq 0$ and $s^{+} \geq 0$. The vector $s^{-} \in R^{m}$ and $s^{+} \in R^{s}$ indicate the input excess and output shortfall of this expression, respectively, and are called slacks. From the conditions $X>0$ and $Y \geq 0$, it holds

$$
x_{0} \geq s^{-}
$$

The SBM model (Tone 2001) can be defined as follows:

$$
\begin{array}{ll}
\min \quad \rho & =\frac{1-\frac{1}{m} \sum_{i=1}^{m} s_{i}^{-} / x_{i 0}}{1+\frac{1}{s} \sum_{i=1}^{s} s_{r}^{+} / y_{r 0}} \\
\text { s.t } \quad x_{0} & =X \lambda+s^{-}, \\
y_{0} & =Y \lambda-s^{+}, \\
\lambda \geq 0, s^{-} \geq 0, s^{+} \geq 0 .
\end{array}
$$

\subsection{Super SBM DEA}

Tone (2001) develops a SBM of efficiency, which directly deals with input and output slacks in DEA. Unlike the additive DEA model (Charnes et al. 1984), Tone (2001) SBM returns efficiency scores between zero and one, as in the radial DEA model (e.g., Charnes et al. 1978). Further, Tone (2002) presents a super-efficiency model for decision making units (DMUs) that are efficient under SBM so that efficient DMUs can be ranked.

Under the radial DEA models, super-efficiency DEA models are obtained simply by removing the DMU under evaluation from the reference set. However, the above procedure cannot be applied directly to non-radial DEA models to yield the superefficiency versions.

As demonstrated in Tone (2002), for non-radial or slacksbased DEA models, one needs to identify the efficient DMUs first and then modify the DEA model.

Suppose that $D M U_{0}$ is an efficient $D M U$, and the super SBM is defined as the optimal value $\delta_{0}^{*}$ to the following problem (Tone 2002):

$$
\begin{aligned}
& \delta_{o}^{*}=\min \delta_{0}=\frac{\frac{1}{m} \sum_{i=1}^{m} \bar{x}_{i 0} / x_{i 0}}{\frac{1}{s} \sum_{r=1}^{s} \bar{y}_{r 0} / y_{r 0}} \\
& \text { s.t } \bar{x}_{i 0} \geq \sum_{j=1, j \neq 0}^{n} \lambda_{j} x_{i j}, \quad i=1,2, \ldots, m, \\
& \bar{y}_{i 0} \leq \sum_{j=1, j \neq 0}^{n} \lambda_{j} y_{r j}, \quad r=1,2, \ldots, s, \\
& \bar{x}_{i 0} \geq x_{i 0} \\
& \bar{y}_{r 0} \leq y_{r 0}, \\
& \lambda_{j}, \bar{y}_{r 0} \geq 0, j=1,2, \ldots, \mathrm{n}, j \neq 0, r=1,2, \ldots, s .
\end{aligned}
$$


In Tone's (2002) super-efficiency model (1), a fractional objective function is used, and additional constraints of $\bar{\chi}_{i 0} \geq \chi_{i 0}$ and $\bar{y}_{r 0} \geq y_{r 0}$ are introduced. Due to the objective function, the model also requires positive input and output data for efficient DMUs, i.e., $\chi_{i j}>0$ and $y_{r j}>0$.

\section{Empirical analysis}

In this section, we measure the financial and operational efficiency of five biggest railway freight companies in Russia RRC1 (JSCo $<$ Frist Freight company $>$ ), RRC 2 (JSCo $<$ Federal Freight company $>$ ), RRC 3 ( $<$ Globaltrans $>$ LLC), RRC 4 ( $<$ Trans Oil $>$ LLC), RRC 5 (PJSCo $<$ Trans Container $>$ ) during 2013-2017. These five companies are the biggest railway freight companies in Russia, which are included in the top 30 freight rail operators. Moreover, we have considered the possibility on data collection problems of operational and financial data. Considering these reasons comprehensively, finally five companies were selected.

Table 1 shows the information of Russia five rail freight operating companies. We employed a secondary data collection technique. Dawson (2009) defines secondary data collection as the gathering of information already researched and presented by other scholars or data obtained from other sources but population. The secondary data was obtained from the annual reports of five selected rail freight operating companies in Russia, and Russian Federal State Statistics Service (ROSTAT). Table 2 shows the information of Russia's five rail freight operating companies.

\subsection{Data}

The assessment of operational and financial efficiency using DEA starts with selection of appropriate input and output measures that can be aggregated into a composite index of overall performance. In our model, the data were chosen based on previous DEA studies reported in literature and also consider the possibility of collecting data.

The measurement of operational efficiency of Russian rail freight companies, we use the two inputs and one output variables. The number of rolling stocks(thousands) and the number of employees as input variables. Petrović et al. (2012) suggested that the efficiency of railway operators depends on the quality of transport organization on the technical reliability of the railway rolling stock number. Freight turnover (billion ton-kilometers) as the output variable.

To estimate the Russian rail freight company's financial efficiency, we use two input and two output variables. The analysis undertakes the measurement of financial efficiency and concerned with the financial (profitability) status of a company. Annual fixed assets (million RUB) and operating expenses (million RUB) are used as input variables, and revenues (million RUB) and net income (million RUB) are used output variables. All the inputs and outputs of Russian rail freight operating companies are briefly described in Table 3 and Table 4.

\subsection{The results of financial efficiency}

We investigate the financial efficiency of five Russian rail freight companies using super-SBM model. Table 5 shows the financial efficiency of Russian rail freight companies from 2013 to 2017. The result shows that only 2 companies namely RRC 4 and RRC 4 categorized as efficient with a score of 1.65 and 1.16, respectively. The lowest financial efficiency scores belong to a 100 percent subsidiary of state-owned-enterprise RRC 2 with a mean value of 0.60 and 50 percent subsidiary of state-

\section{Table 2. List of companies selected for analysis}

\begin{tabular}{|c|c|c|}
\hline No. & Rail freight operating companies & Note \\
\hline 1 & $\begin{array}{l}\text { RRC } 1 \\
(\text { JSCo }<\text { First Freight Company }>\text { ) }\end{array}$ & $\begin{array}{l}\text { UCL Rail (rail), UCL Port (stevedoring services) and VBTH (shipping companies and } \\
\text { shipbuilding). } \\
\text { The largest private railway operator in Russia. }\end{array}$ \\
\hline 2 & $\begin{array}{l}\text { RRC } 2 \\
(\text { JSCo }<\text { Federal Freight Company }>\text { ) }\end{array}$ & $\begin{array}{l}\text { Railway-network-wide operator of freight rolling stock. } \\
\text { The company is a subsidiary of OJSC (Open Joint-Stock Company) Russian Railways. }\end{array}$ \\
\hline 3 & $\begin{array}{l}\text { RRC 3 } \\
<\text { Globaltrans }>\text { LLC }\end{array}$ & $\begin{array}{l}\text { Private freight rail transportation group with operations in Russia, the CIS and the } \\
\text { Baltic countries. }\end{array}$ \\
\hline 4 & $\begin{array}{l}\text { RRC } 4 \\
<\text { TransOil > LLC }\end{array}$ & $\begin{array}{l}\text { The largest private rail operator of rolling stock in terms of transportation and market } \\
\text { share in the segment of rail transport of oil and oil products. }\end{array}$ \\
\hline 5 & $\begin{array}{l}\text { RRC } 5 \\
\text { PJSCo }<\text { Trans Container }>\end{array}$ & $\begin{array}{l}\text { Intermodal container transport and integrated logistics company. The company is a } \\
\text { subsidiary of OJSC Russian Railways. }\end{array}$ \\
\hline
\end{tabular}


Table 3. Descriptive statistics of the Russian rail freight operating companies' financial data from 2013 to 2017

\begin{tabular}{lcccc}
\hline & Average & $S D$ & Max. & Min. \\
Inputs (million RUB) & & & & $38,555.7$ \\
Annual fixed asset & $65,240.4$ & $26,566.3$ & $110,785.8$ & 28,623 \\
Operating expenses & $60,675.9$ & $16,803.4$ & $78,695.6$ & \\
Outputs (million RUB) & & & & \\
Revenues & 73,687 & $17,911.6$ & $100,766.4$ & $51,191.1$ \\
Net income & $8,250.3$ & $5,439.3$ & $16,123.1$ & $-3,630$ \\
\hline
\end{tabular}

Table 4. Descriptive statistics of the Russian rail freight operating companies' operational data from 2013 to 2017

\begin{tabular}{|c|c|c|c|c|}
\hline & Average & $S D$ & Max. & Min. \\
\hline \multicolumn{5}{|l|}{ Inputs } \\
\hline Number of Rolling Stock (Thousands) & $86,073.9$ & $60,037.6$ & 200,192 & 23,244 \\
\hline Number of employees (people) & $2,376.8$ & $1,129.7$ & 5,048 & 1,298 \\
\hline \multicolumn{5}{|l|}{ Output } \\
\hline Freight turnover (billion ton-kilometers) & 203.9 & 137.2 & 434 & 49.1 \\
\hline
\end{tabular}

Table 5. Financial efficiency score of Russian rail freight operating companies

\begin{tabular}{ccccccccc}
\hline DMU & 2013 & 2014 & 2015 & 2016 & 2017 & AVE & Rank \\
RRC 1 & 0.66 & 0.63 & 0.62 & 1.02 & 0.88 & 0.76 & 3 \\
RRC 2 & 0.55 & 0.51 & 0.49 & 0.63 & 0.81 & 0.60 & 5 \\
RRC 3 & 1.13 & 1.05 & 1.03 & 1.02 & 1.57 & 1.16 & 2 \\
RRC 4 & 1.67 & 1.87 & 1.67 & 1.36 & 1.68 & 1.65 & 1 \\
RRC 5 & 0.78 & 0.64 & 0.66 & 0.70 & 0.76 & 0.71 & \\
AVE & 0.96 & 0.94 & 0.89 & 0.95 & 1.14 & 0.98 & \\
\hline
\end{tabular}

DMU, decision making units.

owned-enterprise RRC 5 with a mean value of 0.71 . Average financial efficiency score for all companies for the sample period is 0.98 .

The following Figure 2 showed that financial efficiency trend of five rail freight operation companies. Most operators have not changed dramatically through the period 2013 to 2017 . But in case of RRC 4 seen significant decrease in efficiency in 2016 , however the situation is significantly improved after 2016. The case of RRC 1 financial efficiency increased significantly after reorganization (consolidation with a large operator - OJSC "NTK") at the end of 2015. The efficiency of RRC 2 gradually growing due to annual state support and JSCo RZD.

\subsection{Analysis of operational efficiency}

The results of operational efficiency analysis indicate that for the period from 2013 to 2017,2 companies namely RRC 2 and RRC 3 were efficient with a DEA score of 1.21 and 1.09, respectively. The lowest operational efficiency scores belong to RRC 5 , the container operator primarily handling special rolling stock and RRC 4 with the average efficiency score of 0.79 . Average operational efficiency score for all companies for the sample period represents 0.89 .

Table 6 shows the operational efficiency result of five companies. The result shows that the level of operating efficiency of companies operating several types of rolling stock has been stably high through all examining period.

The following Figure 3 showed that operational efficiency of five operators has changed dramatically for 2013-2017, while the efficiency score of RRC 1 shows a downward trend since 2015 and RRC 5 is stably low untill 2016. As about RRC 3 the operational parameter is stable efficient during all periods.

\subsection{Comparative analysis of financial efficiency and operational efficiency}

The scope of delivery to the network of Russian Railways of new freight wagons from 2003 to 2015 exceeded 700 thousand 


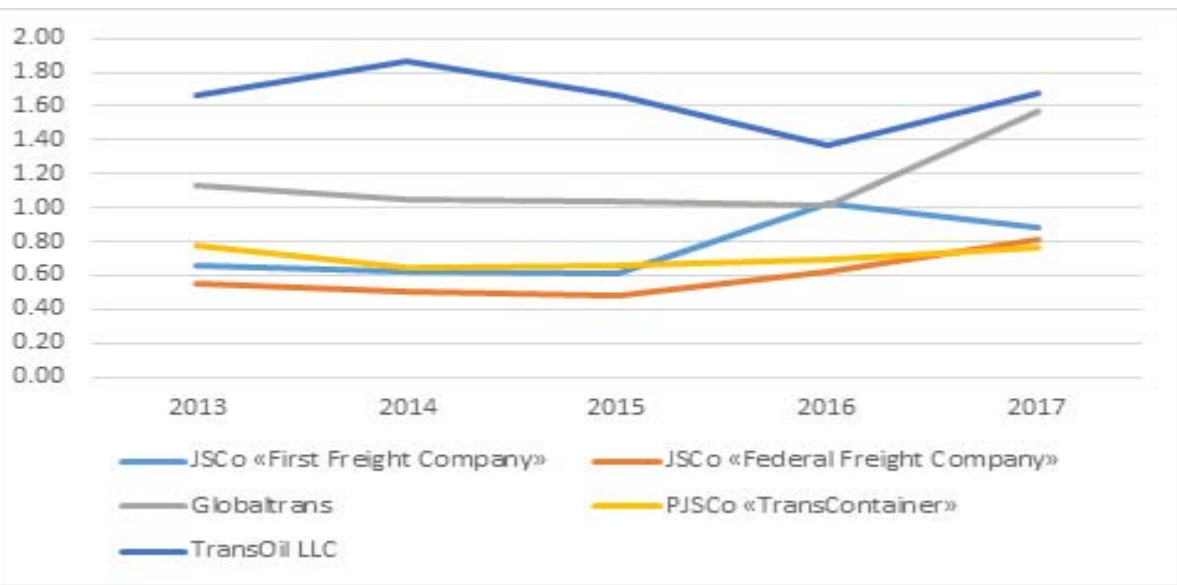

Figure 2. Dynamic of financial efficiency.

Table 6. Operational efficiency score of Russian rail freight operating companies

\begin{tabular}{cccccccc}
\hline Name of the DMU & 2013 & 2014 & 2015 & 2016 & 2017 & AVE & Rank \\
RRC 1 & 1.02 & 1.23 & 0.52 & 1.45 & 0.66 & 0.98 & 3 \\
RRC 2 & 0.72 & 0.93 & 1.69 & 1.03 & 1.66 & 1.21 & 1 \\
RRC 3 & 1.12 & 1.09 & 1.21 & 1 & 1.01 & 1.09 & 2 \\
RRC 4 & 0.81 & 0.82 & 1.33 & 0.45 & 0.55 & 0.79 & 4 \\
RRC 5 & 0.18 & 0.19 & 0.46 & 0.63 & 0.45 & 0.38 & 5 \\
AVE & 0.77 & 0.85 & 1.04 & 0.91 & 0.87 & 0.89 & \\
\hline
\end{tabular}

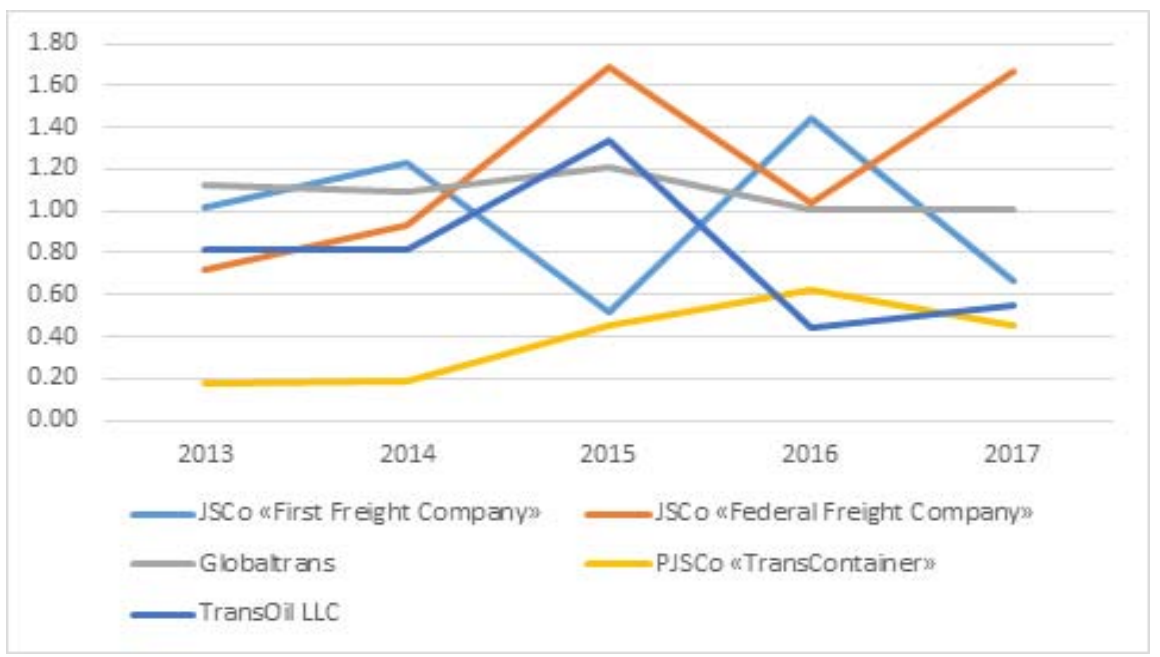

Figure 3. Operational efficiency of five rail freight operator.

units. The main peak of the delivery of freight cars occurred in 2010-2013, when more than 320 thousand freight cars arrived on the network. Speculative interest in investments in the car fleet led to a glut of the market, which led to the formation of a surplus of cars and a deterioration in operating performance during the mass supply of new cars in the future. Table 7 shows the average financial and operational efficiency score of five Russian rail freight operation companies. The private companies characterized by high financial and operational efficiency, while the RZD subsidiaries characterized by sufficiently low financial and operational efficiency scores.

RRC 5 is the only company categorized as inefficient in two dimensions of performance, operational efficiency and financial efficiency. RRC 5 is number one by volume of railway container transportations and has 45 own terminals in all cargo-forming centers of Russia, however, there is high competition on the part of road and sea transport in Russia, which is one of the main 
Table 7. Average financial and operational efficiency score of Russian rail freight operating companies

\begin{tabular}{ccc}
\hline & Financial efficiency & Operational efficiency \\
RRC 1 & 1.16 & 1.21 \\
RRC 2 & 1.65 & 0.97 \\
RRC 3 & 0.60 & 1.09 \\
RRC 4 & 0.76 & 0.38 \\
RRC 5 & 0.71 & 0.79 \\
Average & 0.98 & 0.88 \\
\hline
\end{tabular}

reasons of low efficiency.

Globaltrans Holding provides freight rail transportation, railcar leasing and ancillary services to clients. Consists of rail cars maintenance and repairs (JSCo - Ural Wagonrepair Company), locomotives maintenance and repairs (RemTransServis LLC), freight and cargo (JSCo - New Forwarding Company, FerroTrans LLC, BaltTransServis LLC) and financial support and corporate management (GTI Management LLC). Globaltrans, along with stevedore company Global Ports, is controlled by NTrans Group, which turns to be leading private transport operator in Russia, CIS and Baltic States.

RRC 3 is holding company categorized as efficient in two dimensions of performance financial efficiency and has operational efficiency with score 1.16 and 1.09 respectively. Globaltrans Holding consists not only of Rail freight operating companies (3 operators), but also of Rail cars maintenance and repairs, Locomotives maintenance and repairs and Finance support and corporate management company, that allows to maintain efficiency at a high level.

In the case of RRC 2 shows that is the last company in financial efficiency, but the first company in operational efficiency. RRC 2 is the largest fleet of universal rolling stock of gondola cars, covered cars and universal platforms in Russia, but despite tax breaks for the company, it's not effective in financial aspect through ineffective management and theft of funds by company's top-managers.

Figure 4 shows that operational efficiency scores of operators handling universal rolling stock is higher than financial efficiency scores. Financial and operational efficiency results show that private companies characterized by high financial and operational efficiency, while the RZD subsidiaries characterized by sufficiently low financial and operational efficiency's scores. And the result also presents that operational efficiency scores of operators handling universal rolling stock is higher than financial efficiency scores. In contrast, financial efficiency scores of operators handling special rolling stock is higher than operational efficiency scores. Only one company named RRC 3 shows strong financial and operational performance, average score for the period 2013-2017 is 1.16 and 1.09 , respectively.

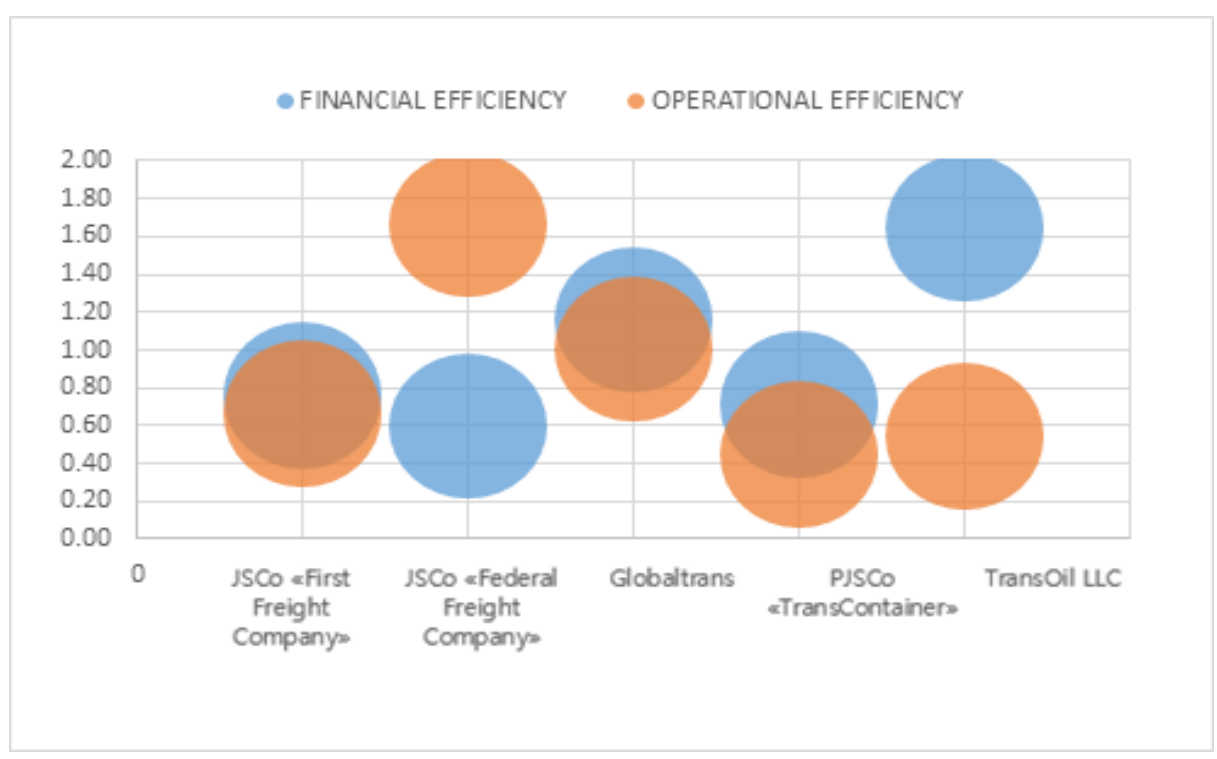

Figure 4. The comparison of financial and operational efficiency 


\section{Conclusions and policy implications}

The transport complex plays an important role in the Russia's economic development. Especially, railway plays an integral part in the movement of freight in Russia, which is the world's largest country with 17 million square kilometers more than $10 \%$ of the Earth's landmass. Therefore, rail transportation could be recognized that is an important part of driving Russia's economy. In Russian, the railway industry is tightly regulated and controlled by the Government. So, the legal aspect and policies of direct government control plays a key role in the Russian rail freight market. The Russia's rail freight market is only at the stage of its formation, for several reasons, the railway transport reform is implemented based on the Program of Railway Sector Structural Reform. One of the difficulties is the fact that currently, there are no criteria in the regulatory framework in Russia that would separate the owner of rolling stock from the operator, as well as to divide operators into groups. However, little attention has been paid to evaluate the performance of rail freight market in Russia and the research is needed to improve and promote efficiency of rail freight market.

This study used a super SBM-DEA model to measure the efficiency of top-five companies rail freight operator which are included in the top 30 rail freight operators in Russia in the period of 2013-2017. Especially, the efficiency scores for rail freight operating companies were calculated in terms of two dimensions - financial and operational efficiency. Based on this, we can draw the major findings with empirical result and practical implications.

First, the result of financial efficiency of five Russian rail freight companies show that only 2 companies namely RRC4 and RRC 3 categorized as efficient with a score of 1.65 and 1.16, respectively. The lowest financial efficiency scores belong to a 100 percent subsidiary of state-owned-enterprise RRC 2 with a mean value of 0.60 and 50 percent subsidiary of state-ownedenterprise RRC 5 with a mean value of 0.71 . Average financial efficiency score for all companies for the sample period is 0.98 . Most operators have not changed dramatically through the period 2013 to 2017. But in case of RRC 4 seen significant decrease in efficiency in 2016, however the situation is significantly improved after 2016.

Second, the result of operational efficiency shows that 2 companies namely RRC 2 and RRC 3 were efficient with a DEA score of 1.21 and 1.09, respectively in the period of from 2013 to 2017. The lowest operational efficiency scores belong to RRC 5 , the container operator primarily handling special rolling stock and RRC 4 with the average efficiency score of 0.79 . Average operational efficiency score for all companies for the sample period represents 0.89 . The level of operating efficiency of companies operating several types of rolling stock has been stably high through all examining period.

Third, the result of comparative analysis for financial efficiency and operational efficiency shows that the private companies characterized by high financial and operational efficiency, while the RZD subsidiaries characterized by sufficiently low financial and operational efficiency scores. RRC 5 is the only company categorized as inefficient in two dimensions of performance, operational efficiency and financial efficiency. RRC 5 is number one by volume of railway container transportations and has 45 own terminals in all cargo-forming centers of Russia, however, there is high competition on the part of road and sea transport in Russia, which is one of the main reasons of low efficiency.

Furthermore, we can draw some practical implications.

First, rail freight operating companies can measure and benchmark with competitors by using the effectiveness of score as a key performance indicator, which can provide important input for effective decision making. Government railway managers can use financial and operational efficiency score, to analyze the effectiveness of subsidizing the rail freight operating company for a given period. The results of the analysis of this study can be adopted for rail transportation industry. It could be, that holding companies are more competitive in rail freight market, because they can provide their own needs (especially locomotive traction). As seen in the study the financial and operational efficiency score of holding company named RRC 3 (Globaltrans LLC) is over one in two aspects that allows to maintain efficiency at a high level. Possibly, rail freight operators in addition to a special rolling stock park, should have a universal rolling stock park for higher profitability. State-owned companies and their subsidiary operate inefficiently in the midst of a market economy in Russia. Rail freight operators for higher level of financial efficiency should be transferred to the private sector.

Second, operators handling universal rolling stock in Russia such as RRC 1 (JSCo <First Freight Company $>$ ) and RRC 2 (JSCo $<$ Federal Freight Company $>$ ) show a higher level of operational efficiency than companies operating special type of rolling stock such as RRC 4 (TransOil LLC (oil and petroleum products rail freight segment)) and RRC 5 (PJSCo TransContainer (container rail freight segment)). Although in financial aspect one of the company operating special types of rolling stock - RRC 4 shows the highest mean of financial efficiency score equal 1.64, while RRC 5 categorized as inefficient with mean of financial efficiency score equal 0.7 and takes second lowest in the rank. In terms of ownership, the private rail freight operators were categorized as efficient in financial aspect for almost all four years. Whereas the subsidiaries of OJSC 
Russian Railways (state-owned company) show the lowest mean of financial efficiency score.

Third, the findings show that the type of rolling stock park impacts on operational efficiency. Rail freight operators handling universal rolling stock park have high operational efficiency level, whereas the efficiency of companies operating special rolling stock depends on composition of park and on the demand for products transported by the type of rolling stock. The study also found that the ownership has an effect on financial efficiency. In Russia private rail freight companies show high financial efficiency score, while the subsidiaries of OJSC Russian Railways categorized as inefficient in the financial aspect.

Fourth, the evaluating of the performance of the Russian rail freight operating companies with super efficiency SBM model can have some implications for the rail freight industry. Rail freight operating companies can measure and benchmark financial and operational efficiency score with competitors by using the effectiveness of score as a key performance indicator, which can provide important input for effective decision making. Government railway managers can use financial and operational efficiency score, to analyze the effectiveness of subsidizing the rail freight operating companies for a given period. In case of the company received a government subsidy and operating efficiency above 1 (considered effective) during the reporting period it is considered necessary to check the expediency of using the financial resources of this company.

The performance evaluation stated in the research paper might be useful in guiding the Federal Antimonopoly Service in analyzing and controlling influence of new legislative acts on the freight operating companies of Russian railway. Also, it might be practical for evaluating company performance to identify violations in the use of government subsidies.

The results of analysis for this study can be useful for decision-makers of the rail transportation industry. It could be, holding companies are more competitive in rail freight market, because they can provide their own needs (especially locomotive traction). As seen in the study the financial and operational efficiency score of a holding company named RRC 3 (Globaltrans LLC) is over one in two aspects that allows to maintain efficiency at a high level. Possibly, rail freight operators in addition to a special rolling stock park, should have a universal rolling stock park for higher profitability. State-owned companies and their subsidiary operate inefficiently in the midst of a market economy in Russia.

There are some limitations and shortcomings in this study that could be addressed in the future study. The limitations of this study are that most important and representative indicators such as ROI for measuring financial performance are not used in the model. And in the future research, a more advanced comparative research should be conducted for financial and operational efficiency.

\section{References}

Analytical Center under the Government of the Russian Federation, 2015. Bulletin on Current Trends in Russian Economy No. 8 Dynamics of freight transportation in Russia. Available at: http://ac.gov.ru/en/publications/14696

Andersen, P., Petersen, N. C., 1993. A procedure for ranking efficient units in data envelopment analysis. Management Science 39, 1261-1264.

Arvidsson, N., 2011. Operational Freight Transport Efficiency: A Critical Perspective. Department of Business Administration School of Business, Economics and Law University of Gothenburg Press, Gothenburg, Sweden.

Atkinson, S. E., Cornwell, C., 1998. Estimating radial measures of productivity growth: Frontier vs non-frontier approaches. Journal of Product Analysis 10, 35-46.

Bookbinder, J. H., Qu, W. W., 1993. Comparing the performance of major American railroads. Journal of the Transportation Research Forum 33, 70-85.

Cantos, P., Maudos J., 2001. Regulation and efficiency: The case of European railways. Transportation Research Part A: Policy and Practice 35, 459-472.

Cantos, P., Pastor, J., Serrano, L., 1999. Productivity, efficiency and technical change in the European railways: A nonparametric approach. Transportation 26, 337-357.

Charnes, A., Clark, C. T., Cooper, W. W., Golany, B., 1984. A development study of data envelopment analysis in measuring the efficiency of maintenance units in the U.S. air forces. Annals of Operations Research 2, 95-112.

Charnes, A., Cooper, W. W., Rhodes, E., 1978. Measuring the efficiency of decision making units. European Journal of Operational Research 2, 429-444.

Chen, Y., Du, J., Huo, J., 2013. Super-efficiency based on a modified directional distance function. Omega 41, 621-625.

Cowie, J., 1999. The technical efficiency of public and private ownership in the rail industry. The case of Swiss private railways. Journal of Transport Economics and Policy 33, 241-251.

Daniel, J. G., 2008. Productivity and efficiency in urban railways: Parametric and non-parametric estimates. Transportation 
Research Part E: Logistics and Transportation Review 44, 84-99.

Farell, P., 1957. DEA in production center: An input-output model. Journal of Econometrics 3, 23-49.

Federal State Statistics Services, 2017. Russia in Figures 2017. Moscow, Russia.

JSC RZD, 2014. Development strategy of Russian railways holding for the period until 2030 (general). Available at: http://eng.rzd.ru/dbmm/download?vp=49\&load=y\&col_id=121\&id=15830\%20Development\%20strategy\%20of\%20Russ ian\%20railways\%20holding\%20for\%20the\%20period\%20until\%202030

JSC RZD, 2016. 2016 annual report of JSC RZD. Available at: http://ar2016.rzd.ru/en

Kabasakal, A., Kutlar, A., Sarikaya, M., 2015. Efficiency determinations of the worldwide railway companies via DEA and contributions of the outputs to the efficiency and TFP by panel regression. Central European Journal Operations Research 23, 69-88.

Kalluru, S., Bhat, K., 2009. Determinants of cost efficiency of commercial banks in India. The IUP Journal of Bank Management 8, 32-50.

Kouachi, M., Talal, A. K., 1998. Modern tools to evaluate the performance of business organizations between theory and practice: The case of public cement companies in algeria. Accounting and Finance Research 4, 26-38.

Lapidus, B., 2014. On the contribution of JSC «Russian Railways» to the formation of the country's GDP and the economic tasks of the company in conditions of tariff restrictions. VNIIZhT Bulletin, Moscow, Russia.

Li, L. B., Hu, J. L., 2010. Efficiency analysis of the regional railway in China: An application of DEA-Tobit approach. Journal of Information and Optimization Sciences 31, 1071-1085.

Marchetti, D., Wanke, P., 2017. Brazil's rail freight transport: Efficiency analysis using two-stage DEA and cluster-driven public policies. Socio-Economic Planning Sciences, 59, 26-42.

Merkert, R., Smith, Nashand A. S. J., Nash, C.A., 2010. Benchmarking of train operating firms: A transaction cost efficiency analysis. Transportation Planning and Technology 33, 35-53.

Movahedi, M. M., Abtahi, S. Y., Motamedi, M., 2011. Iran railway efficiency analysis, using DEA: An international comparison. International Journal of Applied Operational Research 1, 1-7.

Oum, T. H., Waters, W. G., Yu, C., 1999. A survey of productivity and efficiency measurement in rail transport. Journal of Transport Economics and Policy 33, 9-42.

Oum, T. H., Yu, C., 1994. Economics efficiency of railways and implications for public policy: A comparative study of the OECD countries' railways. Journal of Transport Economics and Policy 28, 121-138.

Petrović, D., Bižić, M., 2012. Increasing the efficiency of railway transport by improvement of suspension of freight wagons. PROMET - Traffic \& Transportation 24, 487-493.

Reutov, E., 2017. Creation of the commercial infrastructure of the market of freight rail transportation. The State University of Management, Moscow, Russia.

Sufian, F., 2007. The efficiency of Islamic banking industry: A non-parametric analysis with non-discretionary input variable. Islamic Economic Studies 14, 53-78.

Tone, K., 2001. A slacks-based measure of efficiency in data envelopment analysis. European Journal of Operational Research 130, 498-509.

Tone, K., 2002. A slacks-based measure of super-efficiency in data envelopment analysis. European Journal of Operational Research 143, 32-41.

Yu, M., 2008. Assessing the technical efficiency, service effectiveness and technical effectiveness of the world's railways through NDEA analysis. Transportation Research Part A: Policy and Practice 42, 1283-1294.

Yu, Y., Chih, H., Tsai., K. H., Liao, K. H., 2014. A comparison of ratios and data envelopment analysis: Efficiency assessment of Taiwan Public Listed Companies. International Journal of Academic Research in Accounting, Finance and Management Sciences 4, 212-219. 